\title{
The Ability of Indonesian EFL University Students in Writing an Explanation Text
}

\author{
Yanpitherszon Liunokas \\ yanpiters69@gmail.com \\ Nusa Cendana University, Kupang NTT
}

Received: 03 August 2020 Accepted: 26 November 2020

DOI: $10.24256 /$ ideas.v8i2.1692

\begin{abstract}
This research aims at finding out the students' ability in writing an explanation at first semester students of English Study Program of Nusa Cendana University, Kupang NTT. The researcher focuses on evaluating the students' writing ability in five aspects of writing namely content, organization, grammar, vocabulary, and mechanics. The researcher applied the quantitative method and descriptive analysis design. The research was conducted in August 2019. This research was conducted at First semester students of the English Study Program of Nusa Cendana University, Kupang. The population of this research was First semester students of the English Study Program of Nusa Cendana University, Kupang in the 2020/2021 academic year. The number population is 160 in four classes. The researcher took 5 students from each class as the sample of the research. Therefore, there were 20 students as a sample. The test was used to find out the students' ability in writing explanation text. In collecting data, the researcher asked the students to write an argumentative essay by choosing one of the given topics. To analyze the data, the researcher focused on evaluating the students' writing in five criteria. The result of the research shows that the mean score of the test is 6.86. It shows that the students have an average degree of capability in writing explanation text. The biggest problem for the students in developing an explanation text is the organization (43\%), it followed by the language use (37\%), vocabulary (33\%), content $(30 \%)$, and the smallest problem is mechanics $(30 \%)$. Some factors that hamper the students in writing: 1) the students face difficulties in expressing ideas, choosing appropriate words, and arranging ideas in writing, 2) the students seldom practice their writing skill, 3) the students still find difficulty in using punctuation in writing from, 4) the students do not enrich themselves with knowledge.
\end{abstract}

Keywords: ability of students; explanation text; writing; 


\section{Introduction}

In English learning, writing is an important component. Someone cannot express our ideas or opinion on a piece of paper if we do not have good writing ability. Kern (2000: 172) states that writing is functional communication, making learners possible to create imagined worlds of their own design. Writing as one of four language skills is considered as a difficult skill because the writer should make some aspects in writing such as content, organization, purpose, vocabulary, punctuation, and spelling in a balance way. Writing is one of English language skills that has an important role, either in formal communication or in informal communication. Writing is an instrument of both communication and self-expression.

Writing is one way to express our ideas, opinions, and feelings. When we are difficult or shy to say our ideas, opinions, or feelings to other people, we can do it by writing. In writing, we can express our mind freely, but writing is not an easy work because we have to pay attention to the language use, content, organization, vocabulary and mechanic.

There are some kinds of writing styles. They are: narration, description, exposition, argumentation and explanation. They have difference characteristics or ways in conveying ideas. As a result, In fact, many students get many difficulties when they convey their ideas into English.

In learning English, one of the skills that should be mastered by students is writing an explanation text. The curriculum requires the students to master it. In addition, they need to prepare their skill in writing to face national examination and competence examination. When the students do not have enough skill in writing include writing, they will face some difficulties to compete in the global era. In addition, the students should be ready to work with many types of challenges included skills in writing.

According to Matwin (2006), Explanation text is written to explain how or why something happens. Typically such text consists of description of phenomenon and explanatory sequence. Explanation begins by identifying the phenomenon (thing) that will be explained. (Phenomenon identification.) Then there is an explanation sequence which explains how things work. Example of an explanation: shows the structure and language features.

The characteristic of an explanation text consists of two parts namely structure and language feature. Structure of an explanation text consists of: A general statement about the event or thing, A sequence of explanation and A concluding paragraph. While the language features consists of general and abstract noun, words that show cause and effect, use of timeless present tense and passive voice.

Furthermore, explanation text is a text that explains about a process or sequence of phenomena. There are 2 types of explanation text; sequential and cause and effect. An explanation text is written to explain how and why 
something (natural or socio-cultural phenomena) in the world happen. The text contains the process or sequence of the phenomena. The generic structure of explanation text consists of three components. (1) Title (2) General statement -> Stating the phenomena or issues which are being explained. (3) Explanation -> Stating the series of steps which explain the issues or phenomena. In addition, the language features of explanation text are : Focusing generic participant -> an object or phenomenon which is being discussed, such as; rain, chocolate, etc. Using present tense -> This kind of text mostly applies present tense for its sentences, such as; "rain is the primary source of fresh water for most areas of the world, ......."; Chocolate starts from a tree called cacao tree, and etc. Using chronological connectors, the text applies chronological connectors/chronological connections/ connectives, such as; first, second, third, then, after, after that, finally, so, as a consequence, and etc. Using passive voice -> The text sometimes applies passive form, such as; "... the beans are fermented for about a week, dried under the sun, and shipped to the chocolate maker...". Using noun, pronoun, verb, and etc. -> Like so many other text, explanation text absolutely applies a lot of nouns, pronouns (subject pronoun, object pronoun, possessive pronoun, demonstrative pronoun), action verb, and etc.

Some previous studies related to this research: Nanik Rahmawati (2013), in her research entitled "Analysis of coherence in Argumentative Essay written by the sixth semester students of English Study Program of Bengkulu University. It is found that there are 2 essays were classified as very good essays, 16 as good essays, and 10 essays as poor essays. It is recommended to keep training the students to write coherence in an essay.

Zia Hisni Mubarak et.al. (2013) in their study entitled "An analysis of students 'ability in building cohesion and coherence in Argumentative essays written by the fourth year students of English Department at University of Bengkulu. It is found that the ability of students in building cohesion and coherence in Argumentative essays was low average (3-3.5). It means that the students have low understanding towards some cohesion and coherence. Sari (2011), in her thesis entitled "Sex difference in learning Writing English" reported that there are several differences and similarities of male and female in learning narrative text. These similarities and differences com because there are any different cahracteristics at male and female as basic aspect of term "sex difference".

Akbar (2009) in his thesis which written under title "Improving Student's writing skill through pair interview at eleventh year students of SMAN 2 Palopo", found that there was significant score of students before and after joining treatment with pair interview. It means that through pair interview can improve student's English writing skill at SMAN 2 Palopo. Pahira (2010) in her thesis which written under title 'Improving Students' Writing Skill through Grammar Translation Method. It is found that it is effective to use GTM in developing students' writing skill. 
Those researchers have the same focus with this current research, where those researchers also studied about writing. The special one that makes this research is difference than the previous researchers is the objective of this research focused on evaluating the students' performance in writing an explanation text in the university at east Indonesian namely in Kupang city. It is expected to bring this research as a new information on the theory of the university students' writing difficulties in English teaching and learning development issue.

In this current study, the researcher is interested to see the ability of students in writing an explanation text at First semester students of English Study Program of Nusa Cendana University, Kupang NTT. This research will be entitled "The Ability of Indonesian EFL University Students in Writing an Explanation Text ". Based on the background of this study, the researcher formulates the problem statement as: How is the students' ability in writing an explanation text at First semester students of English Study Program of Nusa Cendana University, Kupang?. Based on the problem statements, the researcher states that the objectives of this research is to find out the students' ability in writing an explanation text at First semester students of English Study Program of Nusa Cendana University, Kupang NTT. There are two kinds of significances of the research, namely ; 1 . Theoretically, the result of this research is expected to give contribution to the development theory of writing especially in writing argumentative essay for learner of English as foreign language. 2. Practically, the research of the research is expected to be a reference for teachers to develop learning methods or other methods or looking for a more effective. The result of the research can be a reference for the teacher and lecturers in teaching writing based on the students' ability. So that they can use the proper method to teach them. This research focused on the writing explanation text. The researcher assessed the students' mechanics in writing by following the Heaton's rubric.

\section{Method}

The researcher applied quantitative method and descriptive analysis design. The researcher finds out the students' ability in writing an explanation essay. The researcher get the data to be analyzed by collecting students' writing assignment. The research was conducted in August 2020. This research was conducted at First semester students of English Study Program of Nusa Cendana University, Kupang.

The population of this research was the First semester students of English Study Program of Nusa Cendana University, Kupang in the 2020/2021 academic year. The number of population is 160 in four classes. To determine the sample, the researcher used random sampling. Therefore, there were 30 students as sample.

In this research, the researcher used writing test as the instrument. The test was used to find out the students' ability in writing explanation text. The test namely was an explanation text. The students' had to make an explanation text. In collecting data, the researcher did the following procedures: (1). The researcher 
determined the sample (2). The researcher came to the class explain to the students about the test. (3). The researcher asked the students to write an explanation text by choosing one of the give topics. In conducting the test, the researcher gave them 60 minutes to finish the test. (4). The researcher collected the result of the test. (5). The researcher evaluated the students' writing

To analyze the data, the researcher focused on evaluating the students' writing by using the ELS composition profile of Heaton JB. (Heaton,1988:100), then the researcher find out mean score of students for each criteria and individually. Then, classifying the students score.

\section{Results}

1. Students' score

Table 1: Students score of writing test in writing an explanation text

\begin{tabular}{|c|c|c|c|c|c|c|c|}
\hline \multirow{2}{*}{$\begin{array}{c}\text { stnednopseR } \\
\text { edoC }\end{array}$} & \multicolumn{5}{|c|}{ erocS } & \multirow[b]{2}{*}{$\begin{array}{l}\text { latoT } \\
\text { erocS }\end{array}$} & \multirow[b]{2}{*}{ erocs } \\
\hline & $\begin{array}{c}C \\
(20)\end{array}$ & $\begin{array}{c}\mathrm{O} \\
(20)\end{array}$ & $\begin{array}{c}\mathrm{V} \\
(20)\end{array}$ & $\begin{array}{c}\text { UL } \\
(20)\end{array}$ & $\begin{array}{c}M \\
(20)\end{array}$ & & \\
\hline 1 & 18 & 16 & 16 & 18 & 18 & 86 & 8.6 \\
\hline 2 & 15 & 14 & 16 & 18 & 15 & 78 & 7.8 \\
\hline 3 & 8 & 12 & 10 & 11 & 13 & 54 & 5.4 \\
\hline 4 & 16 & 13 & 12 & 10 & 12 & 63 & 6.3 \\
\hline 5 & 11 & 14 & 9 & 16 & 10 & 60 & 6.0 \\
\hline 6 & 15 & 15 & 15 & 12 & 15 & 72 & 7.2 \\
\hline 7 & 18 & 15 & 11 & 15 & 15 & 74 & 7.4 \\
\hline 8 & 14 & 11 & 10 & 10 & 11 & 56 & 5.6 \\
\hline 9 & 11 & 12 & 10 & 10 & 12 & 55 & 5.5 \\
\hline 10 & 13 & 14 & 11 & 9 & 10 & 57 & 5.7 \\
\hline 11 & 10 & 10 & 12 & 10 & 9 & 51 & 5.1 \\
\hline 12 & 16 & 17 & 16 & 15 & 15 & 79 & 7.9 \\
\hline 13 & 11 & 12 & 8 & 8 & 9 & 48 & 4.8 \\
\hline 14 & 11 & 14 & 13 & 8 & 10 & 56 & 5.6 \\
\hline 15 & 18 & 14 & 16 & 9 & 15 & 72 & 7.2 \\
\hline 16 & 17 & 17 & 16 & 16 & 12 & 78 & 7.8 \\
\hline 17 & 12 & 11 & 10 & 9 & 9 & 51 & 5.1 \\
\hline 18 & 10 & 15 & 10 & 9 & 11 & 55 & 5.5 \\
\hline 19 & 18 & 17 & 17 & 18 & 18 & 88 & 8.8 \\
\hline 20 & 11 & 10 & 18 & 12 & 10 & 61 & 6.1 \\
\hline 21 & 18 & 17 & 17 & 18 & 15 & 65 & 6.5 \\
\hline 22 & 15 & 15 & 15 & 16 & 11 & 72 & 7.2 \\
\hline 23 & 15 & 15 & 10 & 11 & 15 & 66 & 6.6 \\
\hline 24 & 18 & 17 & 18 & 18 & 18 & 89 & 8.9 \\
\hline 25 & 16 & 18 & 17 & 19 & 18 & 88 & 8.8 \\
\hline
\end{tabular}


The Ability of Indonesian EFL University Students in Writing an Explanation Text

\begin{tabular}{cccccccc}
\hline 26 & 10 & 16 & 17 & 16 & 13 & 72 & 7.2 \\
27 & 16 & 17 & 16 & 13 & 15 & 77 & 7.7 \\
28 & 18 & 18 & 16 & 18 & 17 & 87 & 8.7 \\
29 & 10 & 16 & 13 & 9 & 13 & 61 & 6.1 \\
30 & 15 & 12 & 16 & 11 & 15 & 69 & 6.9 \\
\hline \multirow{2}{*}{ latoT } & $\Sigma \mathrm{X}=3$ & \multirow{2}{*}{$\Sigma \mathrm{X}=416$} & $\Sigma \mathrm{X}=41$ & $\Sigma \mathrm{X}=37$ & $\Sigma \mathrm{X}=36$ & $\Sigma \mathrm{X}=20$ & $\Sigma \mathrm{X}=204$. \\
& 97 & & 3 & 1 & 9 & 60 & 8 \\
\hline
\end{tabular}

This table shows the students score of writing test in writing an explanation text . The table shows that the sum of students' score was 204.8

2. Scoring classification

Students' score of writing test is classified in to some criteria. The criteria and percentage of the student's score of the writing test is as follows:

a. Content

There are four things than can be measured in connecting with content. The composition should content one central purpose only and should have unity and continuity.

Table 2: The criteria and percentage of the student's achievement based on the content

\begin{tabular}{clcc}
\hline NO & Classification & Frequency & Percentage $\%$ \\
\hline 1 & Very good & 8 & 27 \\
2 & Good & 9 & 30 \\
3 & Average & 7 & 23 \\
4 & Poor & 6 & 20 \\
5 & Very poor & - & - \\
\hline & Total & 30 & 100 \\
\hline
\end{tabular}

The data shows that 8 students (27\%) are classified into very good, 9 students (30\%) are classified into good, 7 students (23\%) are classified into average, and 6 students (20\%) are classified into poor.

b. Organization

The purpose of organizing material in writing involves coherent, order of importance, general to specific, chronological order to patter.

Table 3: The criteria and percentage of the students' achievement based on the organization.

\begin{tabular}{clcc}
\hline NO & Classification & Frequency & Percentage $\%$ \\
\hline 1 & Very good & 8 & 27 \\
2 & Good & 13 & 43 \\
3 & Average & 7 & 23 \\
4 & Poor & 2 & 7 \\
5 & Very poor & - & - \\
\hline & Total & 30 & 100 \\
\hline
\end{tabular}


The data shows that 8 students' (27\%) are classified into excellent to very good, 13 students (43\%) are classified into good, 7 students (23\%) are classified into fair to average, and 2 students (7\%) is classified into poor.

c. Vocabulary

The effective use of words will always result good writing in both specific and technical writing, vocabulary is one of components in writing. In expressing ideas, we always deal difficulties with vocabulary which makes us difficult to express idea.

Table 4: The criteria and percentage of the students' achievement based on the vocabulary.

\begin{tabular}{cccc}
\hline NO & Classification & Frequency & Percentage $\%$ \\
\hline 1 & Very good & 6 & 20 \\
2 & Good & 10 & 33 \\
3 & Average & 6 & 20 \\
4 & Poor & 8 & 27 \\
5 & Very poor & - & - \\
\hline & Total & 30 & 100 \\
\hline
\end{tabular}

The data shows that 6 students' (20\%) are classified into to very good, 110 students (33\%) are classified into good, 6 students (20\%) are classified into average, and 8 students (27\%) is classified into poor.

d. Language Use

Language use in writing describes correct language and point grammar.

Table 5: The criteria and percentage of the students' achievement based on the vocabulary.

\begin{tabular}{cccc}
\hline NO & Classification & Frequency & Percentage \% \\
\hline 1 & Very good & 7 & 23 \\
2 & Good & 6 & 20 \\
3 & Average & 6 & 20 \\
4 & Poor & 11 & 37 \\
5 & Very poor & - & - \\
\hline & Total & 30 & 100 \\
\hline
\end{tabular}

The data shows that 6 students' (23\%) are classified into very good, 6 students (20\%) are classified into good, 6 students (20\%) are classified into average, and 11 students (37\%) is classified into poor.

e. Mechanics

Writing, like any other skill, has its 'mechanical' component. These 
include handwriting, spelling, punctuation, and the construction of wail formed sentences, paragraph, and texts.

Table 6: The criteria and percentage of the students' achievement based on the mechanics.

\begin{tabular}{cccc}
\hline NO & Classification & Frequency & Percentage \% \\
\hline 1 & Very good & 5 & 17 \\
2 & Good & 9 & 30 \\
3 & Average & 9 & 30 \\
4 & Poor & 7 & 23 \\
5 & Very poor & - & - \\
\hline & Total & 30 & 100 \\
\hline
\end{tabular}

The data shows that 5 students' (17\%) are classified into very good, 9 students (30\%) are classified into good, 9 students (30\%) are classified into average, and 7 students (23\%) is classified into poor.

3. Mean score of writing test

The mean score of the test is 6.86. It shows that the students have average degree of capability in writing explanation text.

\section{Discussion}

Based on the result of data analysis, the researcher found out that most of the students still make some mistakes in all parts when they write an explanation text.. It can be stated that the students has low competence in writing at First semester students of English Study Program of Nusa Cendana University, Kupang. From the result data analysis, shows that the mean score of the students in test was 6.86 It shows that it is needed for teacher to make some effort in increasing the students' ability in mechanics. The biggest problem for the students in developing an explanation text is the organization (43\%), it followed by the language use (37\%), vocabulary (33\%), content (30\%), and the smallest problem is mechanics (30\%).

Some factors that hamper the students in writing text are : 1) the students face difficulties in expressing ideas, choosing appropriate words, and arranging ideas in writing from, 2) the students seldom practice their writing skill, 3) the students still find difficulty in using punctuation in writing from, 4) the students do not enrich themselves with knowledge. 
From the analysis of students' explanation text writing, it is found that they got some difficulties especially the mechanics. In fact, a student should have a good ability in mechanics especially in writing an explanation text. It is known that an essay is something represents our thinking. As Kiefer (2016), writes that an explanation is writing that explains what a term means. In a way, all essays represent what you think, what you feel, about a given topic. Essays represent your effort to communicate those thoughts and feelings to others. In addition, Pardiyono (2006) states that writing is one way to express our ideas, opinions, and feelings. When we are difficult or shy to say our ideas, opinions, or feelings to other people, we can do it by writing. In writing, we can express our mind freely, but writing is not an easy work because we have to pay attention to the language use, content, organization, vocabulary and mechanic. In addition, Writing English is a skill which so compulsory. So we have to study how to write something. Sometimes, we cannot express our idea orally but we can do freely through writing. Actually, there are still some other parts in writing assessment, namely content, organization, grammar and vocabulary.

In students' writing, most of the students got problem in: (1) The use of capital in the beginning of a sentence. Many of students still use small letter when they write the first letter in the beginning of a paragraph. (2) The students still use some capital letter in the middle of sentences. They write with capital letter in not appropriate position. (3) Some students still do not understand about the of comma and point in a sentence. Based on the data, it can be said that the First semester students of English Study Program of Nusa Cendana University, Kupang, need some help to solve their problem in mechanics. They should be aware with the capital letter use. They should understand about when they need to use capital letter and when it is forbidden to use the capital letter. In addition, the English teacher should give focus on improving the students ability in writing, especially in the mechanics part.

Furthermore. the students seems do not really understand about a good essay. They do not care about the rule of argumentative essay as Kiefer (2016) 
states that there are three steps to make an effective essay writing: (1) Tell reads what term is being defined. (2) Present clear and basic information. (3) Use facts, example, or anecdotes that readers will understand. According to Mark Twain (2009) there are five steps in writing : (1) For the introduction, write the thesis statement and give some background information. (2) Develop each supporting paragraph and make sure to follow the correct paragraph format. (3) Write clear and simple sentences to express your meaning. (4) Focus on the main idea of your essay. (5) Use a dictionary to help you find additional words to express your meaning.

\section{Conclusion}

Based on the findings and discussion, the researcher can conclude that the students still have to improve their ability in writing an explanation. The mean score of the test result is 6.86. It shows that the students have average degree of capability in writing explanation text. The biggest problem for the students in developing an explanation text is the organization (43\%), it followed by the language use (37\%), vocabulary (33\%), content (30\%), and the smallest problem is mechanics (30\%). Some factors that hamper the students in writing: 1) the students face difficulties in expressing ideas, choosing appropriate words, and arranging ideas in writing from, 2) the students seldom practice their writing skill, 3) the students still find difficulty in using punctuation in writing from, 4) the students do not enrich themselves with knowledge.

The researcher would like to present some suggestions below: 1 . The English teacher at First semester students of English Study Program of Nusa Cendana University, Kupang should have effort to improve the students' writing an explanation text. A teacher should give example to the students in order to make them aware about the writing. 2. There are many techniques that can be used by the teacher in teaching writing, the teacher should choose the most appropriate techniques to their students in order to increase the students' ability and their 
motivation can be developed.

\section{References}

Akbar. (2009). Improving Students' Writing Skill through Pair Interview at the Eleventh Year Students of SMAN 2 Palopo. Unpublished Thesis. Palopo: Department of English Education Study program STAIN Palopo

Bram, Barli. (1995). Write Well Improving Writing Skills, Yogyakarta: Penerbit Kanisius.

Depdikbud. (2009). Penilaian Pembelajaran. Jakarta: Depdikbud

Fon, Janice.(2011). Writing System. The Ohio State University.

Gay, Mills and Airasian, L.R. (2006). Educational Research: Competencies for Analysis and Applications. 8 $^{\text {th }}$ Edition.Pearson Education. Inc. New Jersey.

Heaten, J.B. (1988). Writing English language Test. Longman Handbook for Language Teacher. London and New York.

Hogue, Ann. (1981). First Steps in Academic Wriring. Addison-Wesley Publishing Company.

Hornby A.S. (1995). Oxford Advanced Learner's Dictionary. New York : Oxford University Prees.

Keenan, Jhon. (1982). Fed Free to Write. New York ; Wiley and Sons. In Ekawati Impun. 2008. The Difficulties Faced by The Sixth Semester Students of English study Program of Cokroaminoto Palopo University in Writing Essay

Kern. (2000). Writing English Language. London: Longman

Kiefer. (2016). How to Teach Writing. England: Pearson Education Ltd

Mallingerang, Yurni, 2004. The Correlation Between Reading Habit and Writing ability to The Second Class Students of SMS Negeri 3 Palopo. A Thesis S1. Cokroaminoto University Palopo.

Masruddin, M. (2019). Omission: Common Simple Present Tense Errors in Students' Writing of Descriptive Text. Ethical Lingua: Journal of Language Teaching and $\quad$ Literature, 30-39. https://doi.org/10.30605/ethicallingua.v6i1.1114

Masruddin, M., Karmila, K. (2018). Constructing WH-Questions througn An Error Analysis at Junior High School of Indonesia. Langkawi: Journal of The Association for Arabic and English 4 (2), 123-137. DOI: http://dx.doi.org/10.31332/lkw.v4i2.852

Mukhlis, Nurafni. (2005). The Difficulties Faced by The Second Year in Writing Paragraph. A Thesis S1. Cokroaminoto University Palopo.

Munawir, A. (2019). Online Game and Children's Language Behavior. IDEAS: Journal on English Language Teaching and Learning, Linguistics and Literature, 7(2). doi:https://doi.org/10.24256/ideas.v7i2.1050

Nasir, Hapsa. (2004). Writing Ability of The Second Year Student of SMP Negeri 4 Palopo in Reproduction Technique. A Thesis S1. Cokroaminoto University Palopo. 
The Ability of Indonesian EFL University Students in Writing an Explanation Text

Nurul, A. (2019). Anderson Taxonomy-Based Intensive Test Evaluation Tool for Senior High School. IDEAS: Journal on English Language Teaching and Learning, Linguistics and Literature, 7(1). doi:https://doi.org/10.24256/ideas.v7i1.725

Rahmawati, N. (2013). Analysis of coherence in Argumentative Essay written by the sixth semester students of English Study Program of Bengkulu University. Thesis S1, Bengkulu University

Richard, Renadya. (2000). Principle of Language Teaching. Cambridge: Cambridge University Press.

Riska. (2007). Improving Students' Writing Ability throught Free Writing. A Thesis S1. Cokroaminoto University Palopo.

Rotter, W. (1978). Your Companion to English Texts. Kollegstufe/Abitur/University.

Rusdiansyah, R. (2019). Note-Taking as a Technique in Teaching Reading Comprehension. IDEAS: Journal on English Language Teaching and Learning, Linguistics and Literature, 7(2). doi:https://doi.org/10.24256/ideas.v7i2.1033

Sudjana.(1989). Penelitian dan Penilaian Pendidikan. Bandung : sinar baru. In Ekawati Impun. 2008.

Sugiono. (2014). Metode Penelitian, Kuantitatif dan R\&D. Bandung: Alfabeta.

Twain, M (2009). Writing in English. London: Longman 